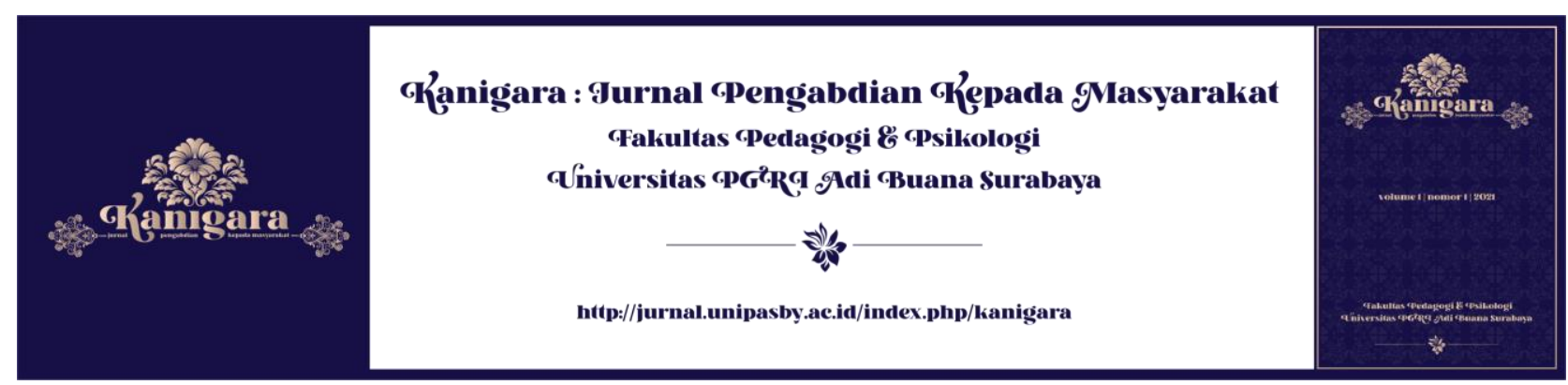

\title{
SPORTS PARENTING DALAM USAHA MENGENALKAN KESEHATAN MENTAL BAGI SISWA KELAS 5 SDN SUKOREJO 1 KECAMATAN REJOSO KABUPATEN NGANJUK JAWA TIMUR
}

\author{
Suharti ${ }^{*}$, Sumardi ${ }^{2}$, Harwanto $^{3}$, Abdul Cholid ${ }^{4}$ \\ Program studi Pendidikan Jasmani \\ Universitas PGRI Adibuana Surabaya \\ Indonesia \\ *Email: suharti@unipasby.ac.id
}

\begin{tabular}{l}
\hline Informasi Artikel \\
\hline Kata kunci: \\
Kesehatan mental, sport \\
parenting
\end{tabular}

Diterima: 15-01-2021

Disetujui: 20-01-2021

Dipubikasikan: 26-012021

\begin{abstract}
Abstrak
Pendidikan jasmani memiliki potensi besar untuk meningkatkan dan mempromosikan gaya hidup sehat, namun itu bukan satu-satunya prioritas, karena pendidikan jasmani memiliki banyak tujuan lain. Pendidikan jasmani bisa berintegrasi dengan bidang studi lainnya di sekolah, karena pendidikan jasmani bersifat holistic. Sementara itu, mengutip detikcom, penelitian oleh dr Nova Riyanti Yusuf, SpKJ, pada kurang lebih 941 siswa sekolah di daerah Jakarta menunjukkan lebih dari 30 persen mengalami depresi dan 18,6 persen di antaranya memiliki keinginan untuk bunuh diri. Oleh karena itu, orang tua harus lebih sensitif terhadap perubahan perilaku yang terjadi pada anak. Pendidikan mental harus selaras dengan pembangunan manusia yang telah dicanangkan oleh pemerintah yang bisa dimulai dari linkungan keluarga dan lingkungan sekolah. SDN Sukorejo 1 kecamatan Rejoso kabupaten nganjuk memiliki potensi mengembangkan program literasi dengan pendampingan guru di sekolah. Tindak lanjut kegiatan ini sangat diperlukan agar peningkatan pola asuh anak terkait dengan kesehatan mental terus akan berjalan denga baik.
\end{abstract}

\footnotetext{
Abstact

Physical education has great potential to promote and promote a healthy lifestyle, but it is not the only priority, because physical education has many other purposes. Physical education can integrate with other fields of study in schools, because physical education is holistic. Meanwhile, citing detikcom, research by dr Nova Riyanti Yusuf, SpKJ, on approximately 941 school students in the Jakarta area showed that more than 30 percent experienced depression and 18.6 percent of them had suicidal thoughts. Therefore, parents must be more sensitive to behavior changes that occur in children. Mental education must be in line with human development that has been proclaimed by the government, which can be started from the family environment and the school environment. SDN 1 Sukorejo Rejoso has the potential to develop literacy programs with teacher assistance in schools. The follow-up of this activity is very necessary so that the improvement of child parenting related to mental health continues to run well.
} 


\section{PENDAHULUAN}

Istilah Literasi fisik di Indonesia masih belum popular seperti di negaranegara maju Kanada, Jepang, Australia, Amerika, Ceko, dan Finlandia. Kalangan akademisi masih sangat minim dalam upaya memperkenalkan atauupun mengkaji lebih mendalam mengenai literasi jasmani, meskipun ada dibeberapa universitas sudah memperkenalkan istilah literasi namun tidak sepenuhnya dipelajari. Literasi membaca, menulis dan berhitung, literasi keuangan, literasi digital adalah literasi yang popular ditelinga masyarakat yang digaungkan oleh para pegiat literasi, media masa dan instansi pemerintah. Tidak ada terdengar di media masa ataupun para pegiat literasi menyebutkan literasi jasmani, padahal literasi jasmani atau melek secara jasmani sama pentingnya, terutama ketika membangun kebiasaan gaya hidup yang aktif untuk meningkatkan kualitas hidup agar terhindar dari berbagai penyakit. Literasi jasmani didapatkan melalui proses pendidikan yang alamiah dan tidak dipaksakan sehingga timbul kesadaraan untuk mengelola dan menjaga kesehatan mulai, proses ini terbentuk sejak masa bayi sampai dewasa (Widodo, 2018). Pembentukan literasi jasmani tidak terlepas dari pendidikan jasmani.

Pendidikan jasmani di Indonesia adalah mata pelajaran wajib yang harus sekolah berikan dan siswa pelajari selama di dalam jenjang pendidikan dasar, menengah dan perguruan tinggi. Pendidikan jasmani berada di kelompok B yaitu kelompok mata pelajaran yang substansinya dikembangkan oleh pusat dan dapat dilengkapi dengan muatan local yang dikembangkan oleh pemerintah daerah (Knight, 2014). Didalam kurikulum sebelumnya pendidikan jasmani hanya mendapat alokasi 2 jam perlajaran, namun kurikulum 2013 memberikan alokasi waktu 3 jam pelajaran perminggunya, ini merupakan kemenangan besar bagi guru penjas (Abdullah, dkk, 2017; Fanny, 2019; Felmie, 2020). Namun waktu yang banyak ini tidak sepenuhnya digunakan untuk mengkampanyekan gaya hidup aktif, mengkampanyekan aktivitas fisik seumur hidup, mengkampanyekan pencegahan penyakit yang berkaitan dengan perilaku hidup sehat. Pendidikan jasmani bukan hanya tentang mempraktikan latihan fisik dan olahraga sehingga siswa kurang diberikan informasi tentang pentingnya aktivitas fisik untuk masa kini dan masa depan mereka.

Pendidikan jasmani memiliki potensi besar untuk meningkatkan dan 
mempromosikan gaya hidup sehat, namun itu bukan satu-satunya prioritas, karena pendidikan jasmani memiliki banyak tujuan lain. Pendidikan jasmani bisa berintegrasi dengan bidang studi lainnya di sekolah, karena pendidikan jasmani bersifat holistic (Musfah, 2012).

Literasi fisik berkaiatan erat dengan proses pendidikan. Pendidikan dan aktivitas fisik adalah bidang yang penting karena setidaknya ada tiga alasan untuk membuatnya menjadi penting. Pertama, anak kecil belajar gerakan sejak lahir, ini dimulai ketika bayi menanggkat kepala, meluruskan lengan dan berbalik sambil berbaring, ketika anak-anak membuat langkah awal untuk berjalan dan berlari (Wau, 2019). Ini adalah fase motorik dari tahap perkembangan individu. Ketika setiap tahap dihubungkan dengan karakteristik tertentu, kemudian, gerakan berlanjut sebagai kegiatan kegiatan yang disengaja dan disengaja mislanya seperti belajar cara menegndarai sepeda, dan skuter berenang. Ini adalah kegiatan yang dipilih anak atapun orangtua. Tidak semua tahu cara mengendarai sepeda. Oleh karena itu, kita berbicara tentang pendidikan di aktivitas fisik yang menjadi bagian dari pendidikan jasmani di sekolah sejak usian sekolah remaja, atau yang menjadi bagain dari rutinitas fisik individu seseorang, kegiatan diwaktu luang atau pelatiahan olahraga. Kedua dalam pelajaran olahraga, siswa juga harus belajar tentang pentingnya aktivitas fisik dan penggunaanya dalam kehidupan sehari-hari atau mendapatkan informasi tentang berbagai cara olahraga, ataupun aturan permainan dan ataupun modifikasi permainan, sejarahnya dan gerakan olimpiade, selanjutnya merekka harus memperoleh informasi tentang kebugaraan fisik, rezim fisik, dasar-dasar pertolongan pertama jika terjadi cedera dll.

Seperti yang dinyatakan dalam program kerangka kerja pendidikan, tujuan kurikuler (Herlina \& Suherman, 2020) secara keseluruhan ini adalah pendidikan tentang aktivitas fisik. Ketiga melalui aktivitas fisik dalam pendidikan jasmani, kami belajar kerjasama dan komunikasi dalam tim, dengan actor, rekan setim, lawan dan wasit. Kami memperloeh pengetahuan tentang dasar-dasar aturan dan karenya kami memperloeh prinsip "permainan yang fair/adil" yang tercermin dalam kehidupan sosial seseorang, kita dapat menghormati actor indovidu menggunakan keterampilan dan kemampuan merekan dan mendukungnya. Sementara itu, mengutip detikcom, penelitian oleh dr Nova Riyanti Yusuf, SpKJ, pada kurang lebih 941 siswa sekolah di daerah 
Jakarta menunjukkan lebih dari 30 persen mengalami depresi dan 18,6 persen di antaranya memiliki keinginan untuk bunuh diri (Affandi, 2019). Oleh karena itu, orang tua harus lebih sensitif terhadap perubahan perilaku yang terjadi pada anak. Misalnya, anak yang pendiam tiba-tiba menjadi lebih agresif atau pemberani tanpa sebab yang jelas. Pendidikan di sekolah diharapkan mampu menjadikan wadah pembimbingan mental anak anak sebelum mereka terjun ke masyarakat luas. Pendidikan mental harus selaras dengan pembangunan manusia yang telah dicanangkan oleh pemerintah yang bisa dimulai dari linkungan keluarga dan lingkungan sekolah.

\section{METODE}

Pada dasarnya bagian ini menjelaskan bagaimana pengabdian masyarakat itu dilakukan. Materi pokok bagian ini adalah: (1) rancangan pengabdian masyarakat; (2) observasi dan sasaran pengabdian; (3) lokasi dan lama pengabdian; dan (4) teknik pelaksanaan pengabdian. Untuk pengabdian masyarakat yang menggunakan alat dan bahan, perlu dituliskan spesifikasi alat dan bahannya. Spesifikasi alat menggambarkan kecanggihan alat yang digunakan sedangkan spesifikasi bahan menggambarkan macam bahan yang digunakan. Pelaksanaan sport parenting yang dilaksanakan di SDN 1 Sukorejo Rejoso Nganjuk, pada kegiatan pengabdian pada masyarakat atau PPM bertujuan untuk mengenal seberapa pentingnya pola asuh orang tua dalam mendukung tumbuh kembang anak, adapun kelompok sasaran dalam kegiatan Pengabdian Kepada Masyarakat ini adalah kelompok Orang Tua dan Siswa di SD N I Sukorejo, Rejoso Nganjuk, Jawa Timur.

Kondisi profil kelompok sasaran memberikan gambaran bahwa geografis sekolah yang menjadi pertimbangan serta masih minimnya pengetahuan orang tua siswa tentang physical literasi. Sebagian besar orang tua dan siswa belum mengetahui betul terkait dengan apa itu kesehatan mental untuk itu perlu disampaikan kepada para orang tua di sdn Sukorejo, Rejoso untuk menetapkan strategi yang tepat untuk memberikan pemahaman terhadap pentingnya melakukan pengenalan Pendidikan mental di sekolah. Kemudian selama ini sebagian besar masyarakat belum melaksanakan dan mewujudkan secara nyata dan terukur terkait dengan physical literasi yang mendukung 
kesehatan mental anak sehingga perlu diadakan pelatihan bagaimana memahami dan menerapkan physical literacy yang berkaitan dengan pendidikan mental di sekolah, untuk itu perlu di berikan bagaimana cara menetapkan strategi yang tepat untuk memberikan pemahaman terhadap pentingnya melakukan aktivitas fisik pendukung kesehatan mental.

Indikator keberhasilan kegiatan ini, dilakukan dengan melihat keterlibatan dan antusias peserta. Keterlibatan peserta dapat dilihat dari absen peserta kegiatan dan antusiame peserta dilihat dari motivasi peserta selama kegiatan berlangsung. Digunakan juga metode angket/kuesioner untuk mengumpulkan data mengenai respons orang tua terhadap pelaksanaan sosialisasi sport parenting.

\section{HASIL DAN PEMBAHASAN}

Pelaksanaan kegiatan sport parenting ini membutuhkan waktu secara menyeluruh selama 2 (dua) bulan. Kegiatan P2M sosialisasi sport parenting ini direncanakan pada minggu pertama atau kedua di bulan oktober sampai nopember. Kegiatan P2M yang semula di targetkan 30 wali murid mengalami penambahan kuota sehingga mencapai 36 wali murid. Hal ini disetujui sesuai dengan hasil diskusi dengan pihak sekolah. Besarnya minat orang tua wali murid menjadi pertimbangan utama dari penambahan jumlah tersebut. Sosialisasi sport parenting ini diisi oleh enam orang narasumber dari Universitas PGRI Adibuana Surabaya, ada tiga materi yang disampaikan, masing masing materi di pandu oleh dua pemateri sehingga jumlah pemateri ada 6 orang. Ada beberapa hal yang patut dibahas pada sosialisasi yang telah dilaksanakan.

Pertama berkaitan dengan Pemahaman Sport Parenting bagi wali murid yang semula dipandang kurang dalam hal pemahaman sport parenting namun setelah mendapatkan penjelasan oleh dua orang narasumber dan diberikan gambaran-gambaran tentang peran penting kegiatan sport parenting bagi orang tua, semangat wali murid makin terlihat antusias ketika disinggung dampak pola asuh terhadap tumbuh kembang anak.

Kedua yang perlu dibahas adalah Kesehatan Mental Anak di sekolah dan keluarga. Setelah memberikan penjelasan tentang materi tersebut wali murid bersemangat melakukan tanya jawab dengan pemateri. Sedangkan materi ketiga yang disampaikan adalah tentang Model Pembelajaran Kesehatan Mental bagi 
anak untuk guru dan orang tua. Ketiga materi yang telah disampaikan memberikan dampak perubahan pada wali murid dalam pemahamannya tentang pentingnya pola asuh yang harus dilakukan sejak dini, karena pola asuh mempengaruhi tumbuh kembang dan karakter anak.

\section{KESIMPULAN}

Adapun kesimpulan yang dapat ditarik setelah pelaksanaan P2M sport parenting dalam usaha mengenalkan kesehatan mental bagi siswa kelas 5 di SDN Sukorejo 1, Kecamatan Rejoso Kabupaten Nganjuk ini adalah sebagai berikut: 1) Program P2M dapat terlaksana secara baik dan lancar. 2) Program P2M ini mampu meningkatkan pengetahuan wali murid, kemampuan yang dimaksud meliputi: a. kemampuan memahami sport parenting b. kemampuan memahami Kesehatan Mental Anak di sekolah dan keluarga. c. kemampuan memilih model pembelajaran kesehatan mental bagi anak.

\section{SARAN}

Tindak lanjut kegiatan ini sangat diperlukan agar peningkatan pola asuh anak terkait dengan kesehatan mental terus akan berjalan dengan baik.

\section{DAFTAR PUSTAKA}

Abdullah, A. G., Hamidah, I., Aisyah, S., Danuwijaya, A. A., Yuliani, G., \& Munawaroh, H. S. (Eds.). (2017). Ideas for 21st Century Education: Proceedings of the Asian Education Symposium (AES 2016), November 22-23, 2016, Bandung, Indonesia. Routledge.

Affandi, A. A. (2019). Perbedaan kesabaran ditinjau dari kepribadian BigFive (Doctoral dissertation, UIN Sunan Ampel Surabaya).

Fanny, A. M. (2019, March). Analysis Of Pedagogical Skills And Readiness Of Elementary School Teachers In Support Of The Implementation Of The 2013 Curriculum. In International Conference on Bussiness Law and Pedagogy (Vol. 1, No. 1, pp. 59-63).

Felmie, E. H. (2020). Kemampuan Guru dalam Penerapa Kurikulum 2013 pada Pembelajaran Pendidikan Jasmani Olahraga dan Kesehatan di Sekolah Dasar Negeri Kecamatan Pulau Punjung Kabupaten Dharmasraya (Doctoral dissertation, Universitas Bung Hatta).

Herlina, H., \& Suherman, M. (2020). Potensi Pembelajaran Pendidikan Jasmani Olahraga Dan Kesehatan (Pjok) Di Tengah Pandemi Corona Virus Disease (Covid)-19 Di Sekolah Dasar. Tadulako Journal Sport Sciences And Physical Education, 8(1), 1-7.

Knight, Camilla. (2014). Parent Guide: Evidence-based strategies for Parenting in Organized Youth Sports. Utah: Utah State University Families in Sport Lab. 
Musfah, J. (2012). Pendidikan holistik: pendekatan lintas perspektif. Prenada Media.

Wau, M. G. (2019). Asuhan Kebidanan Berkelanjutan pada Ny. BKM di Puskesmas Waiwerang Periode 23 April-04 Juni 2019 (Doctoral dissertation, Poltekkes Kemenkes Kupang).

Widodo, A. (2018). Makna dan Peran Pendidikan Jasmani Dalam Pembentukan Insan Yang Melek Jasmaniah/Ter-Literasi Jasmaniahnya. Motion: Jurnal Riset Physical Education, 9(1), 53-60. 